\title{
Agronomic survey to assess crop yield, controlling factors and management implications: a case-study of Babati in northern Tanzania
}

\author{
J. Kihara $\cdot$ L. D. Tamene $\cdot$ P. Massawe $\cdot$ \\ M. Bekunda
}

Received: 15 April 2014/Accepted: 11 October 2014/Published online: 21 October 2014

(C) The Author(s) 2014. This article is published with open access at Springerlink.com

\begin{abstract}
Improved agronomic management is important to reduce yield gaps and enhance food security in sub-Saharan Africa. This study was undertaken to understand contributing factors to observed yield gaps for maize in farmer fields and to demonstrate appropriate agronomic survey methods. The study aimed to (1) demonstrate an approach for farmlevel agronomic survey, (2) identify key crop production constraints and (3) define the nutrient input and output balances of different fields. Agronomic survey was conducted in 117 farmer fields randomly distributed in a $10 \mathrm{~km}$ by $10 \mathrm{~km}$ block in Babati, northern Tanzania. A semi-structured questionnaire and production measurements were used to collect data which
\end{abstract}

\section{J. Kihara $(\bowtie)$}

International Center for Tropical Agriculture (CIAT), c/o ICIPE Duduville Complex, Off Kasarani Road, PO Box 823-00621, Nairobi, Kenya

e-mail: j.kihara@cgiar.org

L. D. Tamene

International Center for Tropical Agriculture (CIAT), c/o Chitedze Agricultural Research Station,

PO Box 158, Lilongwe, Malawi

P. Massawe

Selian Agricultural Research Institute (SARI),

PO Box 6024, Arusha, Tanzania

\section{Bekunda}

International Institute for Tropical Agriculture (IITA), c/o AVRDC, The World Vegetable Center, Duluti,

PO Box 10, Arusha, Tanzania were analyzed with regression classification and mixed effect models. The exploitable maize yield gap at farm-level reaches up to $7.4 \mathrm{t} \mathrm{ha}^{-1}$, and only $<5 \%$ of fields achieve maize grain yield of $5 \mathrm{t} \mathrm{ha}^{-1}$. Slope, plant density, distance from homestead, crop variety, timing of planting and period since conversion significantly influenced maize yields. For example, fields on flat land had up to $1.6 \mathrm{t} \mathrm{ha}^{-1}$ more maize grain yield than those on steep slopes while fields with plant density $>24,000$ plants ha ${ }^{-1}$ had $900 \mathrm{~kg} \mathrm{ha}^{-1}$ more yield than those with less density. At least $52 \%$ of the fields had negative nutrient balances. We conclude that cropping systems used in Babati should be preferentially supplemented with mineral fertilizers while optimizing plant density, increasing manure application and appropriate varietal choice in order to reduce the yield gaps.

Keywords Agronomic survey · Plant density · Yield gap $\cdot$ Regression tree $\cdot$ Nutrient balances

\section{Introduction}

Small-scale agriculture is crucial to food security as it is the main source of food in the developing world, producing up to $80 \%$ of the food consumed in many developing countries, notably in sub-Saharan Africa (SSA) and Asia (Arias et al. 2013). However it's present role to enhancing food security, especially in 
SSA is lower than in other regions, as evidenced by a higher yield gap between farmers' yields and potential yields than that in Europe and America (Muller et al. 2012). Though the high yield gap in Africa presents an opportunity for yield increases (Muller et al. 2012), yield improving factors at the level close enough to the farmer must first be understood. It is also essential to better understand the small-scale farm production constraints in SSA to design intervention plans and target nuanced investments and policy support to boost smallholder farm output (Arias et al. 2013). As specific constraints dictate the productivity and yield potential of different regions, region-specific management changes and interventions are required to close the observed yield gap (Muller et al. 2012). Though irrigation, fertilizer use and climate are identified as the most important factors that determine grain yield at global scale, evidences show that fertilizer alone can bridge $50 \%$ of the yield gap in SSA (Muller et al. 2012). However, these global factors may not always be the most important factors at farm-level, especially if agronomic management practices are not optimized. In SSA, agronomic practices are suggested as key constraint to crop production. As such, local-level grain yield estimation and corresponding evaluation of management practices are needed to understand major drivers and opportunities. An example of such is a study by Oliver and Robertson (2013) who quantified farm-scale yield gaps and attributed the causes to soil fertility variation and farm landscape. However, this study was based on precision farming technologies, which are not applicable to farming systems in SSA where farms are much smaller and fragmented and under variable management. There is therefore a need to understand contributing factors to observed yield gaps and this study demonstrates appropriate agronomic survey methods in order to achieve this.

Yield gaps within an area and among farming households can be associated with agronomic management practices (Fanadzo et al. 2011). However, inexpensive approaches for the identification of these practices have not been well documented. Yield gap can be assessed based on best performing fields or cultivar potential as the benchmarks and we show both cases in this study. The high performing fields can be associated with locally adapted (or imported superior) management practices that in many cases are hardly adopted by a handful of farmers. Identifying differences in such management practices can inform scaling out options as researchers learn from farmers. The identification of best practices is not only the starting point of technology testing and promotion jointly with farmers but is also key to the enhancement of input use efficiencies. For example, fertilizer use is likely to go up following increased investment in agriculture by governments and availing technologies that guarantee efficiency will result in optimization of the inputs. Identification of agronomic management practices in SSA is thus an important entry point towards increasing food productivity and reducing the within site yield gaps. In this article we demonstrate an agronomic survey approach which we used to determine gaps and variability in maize grain yield between different farmer fields and identify the key determinant factors so as to develop strategies of improving the less-productive low-yield farms through technology transfer such as co-learning. We particularly aimed to (1) demonstrate an approach for farm-level agronomic survey, (2) identify the key crop production constraints and (3) define the nutrient input and output balances of different fields.

\section{Methodology}

Description of study site

The study was conducted in the Babati district of Northern Tanzania (between Dareda and Bashnet, Fig. 1), located at around latitude -4.264 and longitude $35.488^{\circ}$. Altitude varies from 1,635 to 2,200 m.a.s.l. in the study site. The area is characterized by low fertilizer use and has one growing season between November and June. Maize is mainly grown as an intercrop with Mali (ICEAP 00040), a latematuring pigeonpea (Cajanus cajan L. Millsp.) cultivar. Previous studies have shown that intercropping this long duration pigeonpea (maturity in up to 300 days; Silim et al. 2007) with maize does not affect the yield of the maize crop in the study site (Myaka et al. 2006) and elsewhere in Tanzania (Kimaro et al. 2009). Following this, only maize yield was directly monitored through field measurements. Planting of maize and pigeonpea takes place starting late November (pigeonpea planted 0-14 days after the maize), and while maize is ready for harvest in April or May, pigeonpea harvest takes place several months later in September and October. 
Fig. 1 Map of study site showing locations (red dots) of the fields sampled in Babati, Tanzania. (Color figure online)
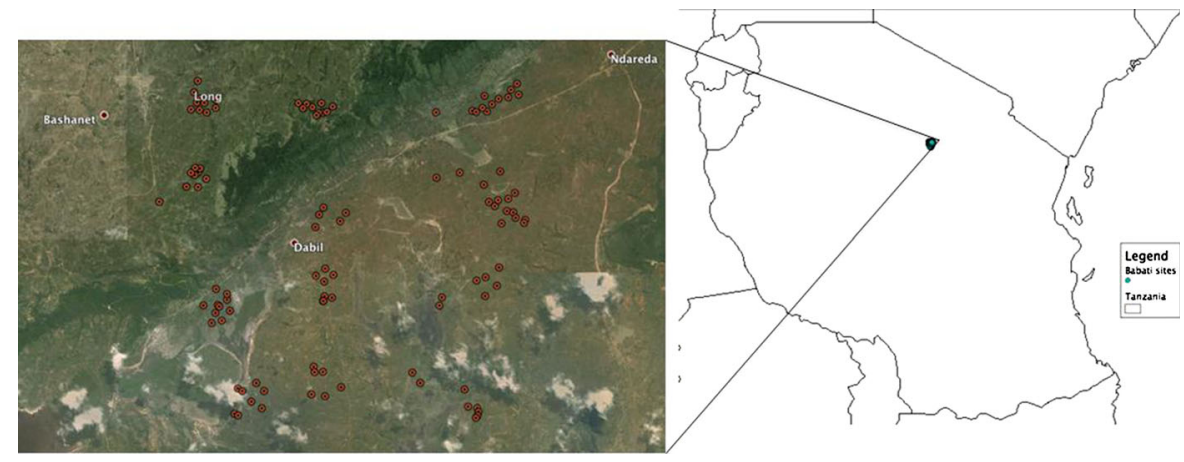

\section{Soil sampling}

Stratified random sampling was used to obtain 32 soil samples (16 at $0-20 \mathrm{~cm}$ and another 16 at $20-50 \mathrm{~cm}$ depth) from a $10 \mathrm{~km}$ by $10 \mathrm{~km}$ block that constituted the study area. The $10 \mathrm{~km}$ by $10 \mathrm{~km}$ block had been stratified into 16 clusters and within each cluster 10 random sampling plots had been randomly assigned. Only one of the 10 plots in a cluster was sampled, by bulking samples augured from four points based on a y-sampling methodology. The soil samples were analysed for $\mathrm{P}, \mathrm{K}, \mathrm{Ca}, \mathrm{Mg}, \mathrm{Cu}, \mathrm{Fe}, \mathrm{Zn}, \mathrm{B}$ and $\mathrm{S}$ based on Mehlich 3 extraction procedure, for $\mathrm{pH}$ determined in water at Crop Nutrition (CropNut) laboratory in Nairobi, for $\mathrm{C}$ and $\mathrm{N}$ at Iso-Analytical Ltd (http:// www.iso-analytical.co.uk/) in United Kingdom and for texture at the ICRAF laboratory in Nairobi. Soil texture was determined as water dispersed particles after 4 min of ultrasonification.

\section{Agronomic survey}

In agronomic survey, key datasets are required to understand the associated production constraints and these are described here. Data on maize harvest and agronomic practices (field history and management of current crop including type of cropping system, residue use, fallowing, frequency of manure application, plant density, thinning, weeding frequency and herbicide use, number of years field is under cultivation, timing of planting, variety, slope and distance of field from homestead) were obtained from 117 farmer fields during the 2012/13 cropping season (see Fig. 1 on distributions and locations of the fields studied). The farmer fields were selected using stratified random sampling where 10 pre-determined and geo- referenced soil sampling plots within each of the 16 clusters as implemented in the Africa Soil Information Service (AfSIS) Land Degradation surveillance Framework (LDSF; http://www.africasoils.net) were chosen to ensure representativeness. Ideally, 160 GPS coordinates, i.e., 10 sampling plots in each of the 16 clusters were the plots/fields targeted for this study. Where the geo-referenced plot was located in a nonmaize cropping field, the nearest adjacent maize field was sampled although it was not possible to get replacement fields in all cases, e.g., where the entire cluster was forested, hence only 117 fields were surveyed. Three enumerators, who had been trained in April 2013, pre-tested the tool together with scientists during the same month, and then conducted the surveys in all the 117 fields (between April and July 2013). For each farmer field, the agronomic management information were obtained based on a questionnaire as well as on observations (e.g., weed condition) from a $10 \mathrm{~m}$ by $10 \mathrm{~m}$ farm section (main plot) followed by harvesting maize in a $3 \mathrm{~m}$ by $3 \mathrm{~m}$ subplot at each end of one of the main plot diagonals. This involved two field visits: a first visit where the $10 \mathrm{~m}$ by $10 \mathrm{~m}$ plots were marked out (maize was about flowering) and field history information recorded, and a second visit (13th June to 4th July 2013) for harvesting of the subplots in the marked out portions. All the maize plants in the $3 \mathrm{~m}$ by $3 \mathrm{~m}$ subplots were harvested, cobs separated from stovers and each component weighed. A subsample of five cobs was selected ensuring that it represented the sizes and the moisture content of all the cobs. These were oven-dried for $48 \mathrm{~h}$ at $60{ }^{\circ} \mathrm{C}$ and dry weights of cores of the maize ear and grain taken. Potential yields for the most common varieties were obtained from a Tanzania variety checklist. 
Timing of planting is one of the important factors that affect crop growth and development and eventually yield. We noted planting data for each farm observed which was taken as number of days since the onset of rains, which corresponds, in our case, with the earliest planting date recorded. For slope, four categories were used for each farm, being flat, very gentle, gentle and steep slope fields.

In agronomic survey, each field represents a unique case. For instance, for fields very close to the homestead, some farmers remove some maize plants for cob-roasting, or food security stop gap measure and only a proportion of cobs remain at harvest. In some cases, stumps are clearly visible while in others they are not. We enquired from the farmers reasons for seen gaps (wide spacing especially where quite irregular). This helped to adjust yield through a ratio of expected plants and plants at harvest. No adjustment was performed for plants lost following poor germination or establishment (since these did not utilize inputs).

Gibberela induced cobrot was widespread, affecting mainly the tips of cobs. In such cases, the cob was broken to separate the affected and unaffected parts in the same way as commonly done by farmers in the study area. These were used in the yield calculations showing the level of pre-harvest yield losses. This indicates the minimum losses since weights could underestimate the lost yield, i.e., affected cobs are in some cases much lighter than unaffected cobs of the same size.

Nutrient balance within each farm plot was estimated based on easy to measure 'nutrient removals' and 'nutrient addition' processes. Nutrient removals were in the form of maize grain and stover yield, and bean and pigeonpea grains and haulms (stems, shells and other non-grain aboveground biomass excluding litterfall). Nutrients additions were in the form of manure and for $\mathrm{N}$, a proportion of legume roots and litterfall from legume crops grown during the previous season to account for biological nitrogen fixation (BNF). Maize grain N, P and K was taken as 1.2, 0.18 and $0.3 \%$, respectively based on previous work by Myaka et al. (2006) in Tanzania. Similarly, stover N, P and $\mathrm{K}$ values of $0.48,0.06$ and $1.7 \%$, respectively are used. Values for common bean grain and haulms N, P and $\mathrm{K}$ content were obtained from Rubyongo (Personal Communication). Litterfall, shell, stem and leaves from pigeonpea were assumed to be 2.5, 0.73,
4.01 and 0.51 times the grain yield based on 3 year average data for Babati (Myaka et al. 2006) while roots are $42 \%$ of the stems + leaves (Ahiabor and Hirata (2003)), and that from common beans was assumed to be $10 \%$ of yield. Pigeonpea grain, shell, stem and leaves $\mathrm{N}$ content used are 3.5, 1.2, 0.8 and $3.2 \%$, and $\mathrm{P}$ content is $0.32,0.17,0.2$ and $0.21 \%$, respectively based on data from Myaka et al. (2006) and Høgh-Jensen et al. (2007) while N content for roots is taken as $2 \%$. Litterfall used for $\mathrm{N}$ input was assumed to contain $1.6 \% \mathrm{~N}$ (Høgh-Jensen et al. 2007). For leaves, we use values for litter since most leaves are fallen when stems are removed from the cropping field. Farmyard manure (FYM) was not analysed in our study but instead average values for East Africa of $1.62 \% \mathrm{~N}, 0.5 \% \mathrm{P}$ and $1.43 \% \mathrm{~K}$ (see Kimani and Lekasi 2004; Paul et al. 2009) were used. Difficult to measure nutrient losses out of the systems such as through leaching, erosion, overland and lateral transport, atmospheric and erosional depositions were not included in this study.

Data analysis methods

Yield data from the 117 farmer fields were sorted in increasing order and plotted to show the yield gaps based on the observed yields. Lines showing the potential yields of the most commonly used varieties were superimposed on the graph of yields.

Regression classifications were constructed in $\mathrm{R}$ statistical software (http://www.r-project.org/) using the Recursive Partitioning and Regression Trees (rpart) package selecting anova as the method of splitting (defining branches) while the plots were made using prp package. Cropping system, residue use, and fallowing are uniform across all fields in our study site in Babati so these were not included in the regression models. The model used in the regression classifications was:

maize grain yield $=f\left(\mathrm{x}_{\mathrm{i}} \ldots \mathrm{x}_{\mathrm{n}}\right)$,

where $\mathrm{x}$ is yield-influencing factors of slope, frequency of manure application, plant density, distance of field from homestead, thinning, weeding frequency, number of years field is under cultivation, timing of planting, variety and herbicide use. For variety, we picked the five varieties mostly used by the farmers and grouped the minor improved seeds together. Also, although only two farmers used recycled seed, a 
recycled category was used due to its importance in yield reduction. Further, a prediction model was developed in $\mathrm{R}$ using linear mixed effects models, the lme4 package, to determine the effect of the different factors on maize grain yield. The prediction model was similar to the regression classification except for village that was added as random factor, i.e.,

maize grain yield $=f\left(\mathrm{x}_{\mathrm{i}} \ldots \mathrm{x}_{\mathrm{n}}\right)+(1 \mid$ village $)$,

Each of the yield influencing factors were omitted from the full model one by one and the effect was evaluated by comparing the full model with the model lacking one of the yield influencing factors using anova. Factors whose omission resulted in a significant $P$ value $(P<0.05)$ when the two models were compared in anova were retained in the prediction yield modeling. The effect of variety and time of planting on yield loss due to cobrot were evaluated using the mixed model:

$\mathrm{y}_{l} \sim$ variety + time of planting $+(1 \mid$ village $)$,

where $\mathrm{y}_{1}$ is yield loss due to cobrot.

\section{Results}

Soils in the study site are of moderate $\mathrm{pH}$ and have limitations of $\mathrm{P}, \mathrm{S}$ and $\mathrm{Zn}$ (Table 1).

Figure 2 shows maize grain yields observed in 117 farmer fields in Babati, in Northern Tanzania. The harvest data shows huge deviations from the potential

Table 1 Concentrations of key nutrients within top and subsoil in the study site in Babati, northern Tanzania

\begin{tabular}{|c|c|c|}
\hline Parameter & Topsoil & Subsoil \\
\hline $\mathrm{pH}$ (1:25 water) & $6.5(0.87)$ & $6.3(0.97)$ \\
\hline $\mathrm{C}(\%)$ & $1.78(0.75)$ & $1.22(0.61)$ \\
\hline $\mathrm{N}(\%)$ & $0.17(0.08)$ & $0.11(0.06)$ \\
\hline $\mathrm{P}\left(\mathrm{mg} \mathrm{kg}^{-1}\right.$ soil $)$ & $47.4(54.7)$ & $27.2(46.3)$ \\
\hline $\mathrm{S}\left(\mathrm{mg} \mathrm{kg}^{-1}\right.$ soil) & $9.5(4.2)$ & $12.3(6.5)$ \\
\hline B ( $\mathrm{mg} \mathrm{kg}^{-1}$ soil $)$ & $0.66(0.42)$ & $0.55(0.28)$ \\
\hline $\mathrm{Zn}\left(\mathrm{mg} \mathrm{kg}^{-1}\right.$ soil) & $3.1(2.39)$ & $1.8(2.08)$ \\
\hline $\mathrm{Mn}\left(\mathrm{mg} \mathrm{kg}^{-1}\right.$ soil $)$ & $148.7(76.8)$ & 106.8 \\
\hline $\mathrm{Na}\left(\mathrm{mg} \mathrm{kg}^{-1}\right.$ soil) & $32.6(15.4)$ & $48.6(39.4)$ \\
\hline PSI (meq/100 g) & $98.6(34.8)$ & $124.6(34.3)$ \\
\hline CEC (meq/100 g) & $19.5(11.5)$ & $20.5(19.2)$ \\
\hline
\end{tabular}

Numbers in brackets are standard deviations yield for some selected varieties. The maize varieties used by farmers were SC627 (39\% of farmers), H614D $(8.5 \%)$, local varieties plus some mixed varieties (19\%), DK 8031 (11\%), Pioneer (7.7 \%), other improved seed such as Pannar 691, SC403, SC513, and H628 (12.8\%) while recycled improved seeds were used by $1.7 \%$ of the sampled farmers. Based on farmer observed maize grain yields, the exploitable yield gap (taken conservatively as the yield difference from the 75th percentile) is $1.6 \mathrm{t} \mathrm{ha}^{-1}$ for the 25th percentile and $0.7 \mathrm{t} \mathrm{ha}^{-1}$ for the 50th percentile. The difference between the highest and lowest observed yield is $7.4 \mathrm{tha}^{-1}$. Based on potential yield for the improved seeds as provided by breeders (see Fig. 2), the yield gap is high since only $<5 \%$ of fields had yield of at least $5 \mathrm{t} \mathrm{ha}^{-1}$. Strategies are needed to reduce these yield gaps while still addressing sustainability issues of the production base. Despite that over $81 \%$ of the farmers claimed to use improved seeds with the remaining using local varieties, only $3 \%$ applied fertilizers on maize as foliar fertilizer. Unique cases are observed for example in field with the very high yield where every plant had two cobs, and in poor yield where farmers used previous harvest of improved maize crop as seed.

Maize was planted between 7th November 2012 to 2nd February 2013 and distribution of this is shown in Fig. 3a. Farmers at high elevation, a village called "Long", planted earlier compared to farmers in the lowlands. Spacing between rows of maize varied between 55 and $110 \mathrm{~cm}$ and the average was $80 \mathrm{~cm}$ (data not shown). As such, most farms had a harvest plant density of between 14,000 and 45,000 plants per hectare (Fig. 3b). A few farmers had a density beyond the expected maize plant population of 44,444 plants per hectare for the plant spacing recommended in the area in intercropping systems. Only two farmers deliberately reduced their plant density to accommodate two inter rows of beans and pigeon pea. Manure use among farmers varied greatly. For the last 5 years, $48 \%$ of the farmers applied manure every season while $36 \%$ did not apply manure in any of the five seasons. Also $16 \%$ applied manure in one, $10 \%$ in 2, $5 \%$ in 3 and $2 \%$ in four out of the five seasons. In general, the amount of manure applied increased with increasing frequency of application (Fig. 3c), and although the mean application rate was about $3.5 \mathrm{t}$ manure ha ${ }^{-1}, 10$ farmers applied more than $10 \mathrm{t} \mathrm{ha}^{-1}$. 
Fig. 2 Maize grain yield observed in Babati

Tanzania, in 2012-2013 cropping season. Solid lines indicate the actual potential yield of selected improved varieties grown by farmers. Broken lines indicate the lower potential yield of the improved varieties where data provided was a range

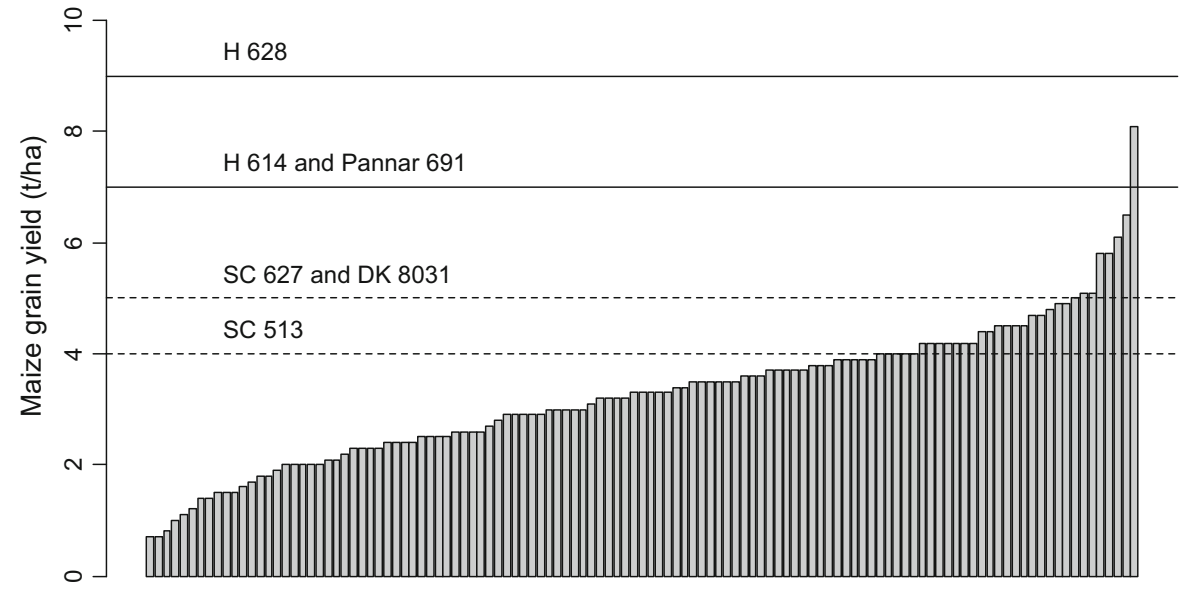

Fields ordered by increasing maize grain yield (a)

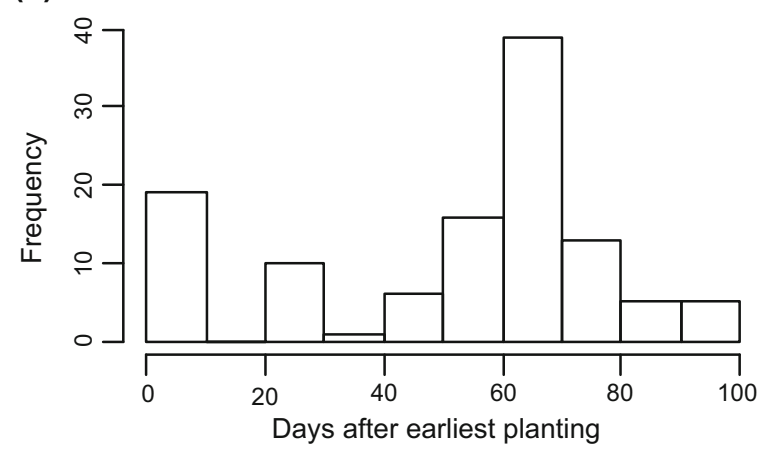

(c)

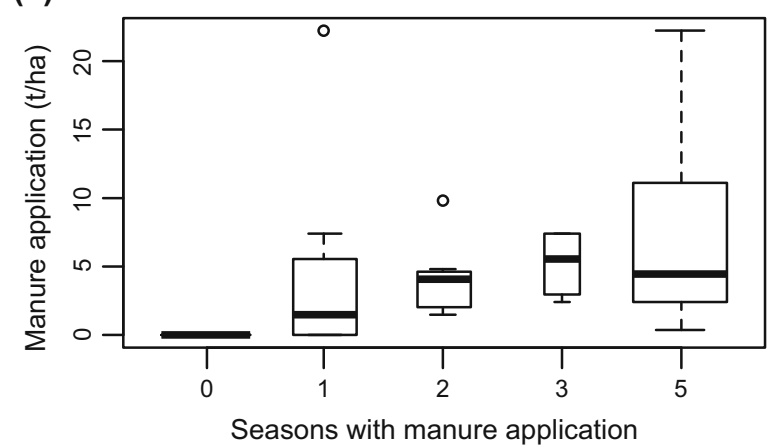

(b)

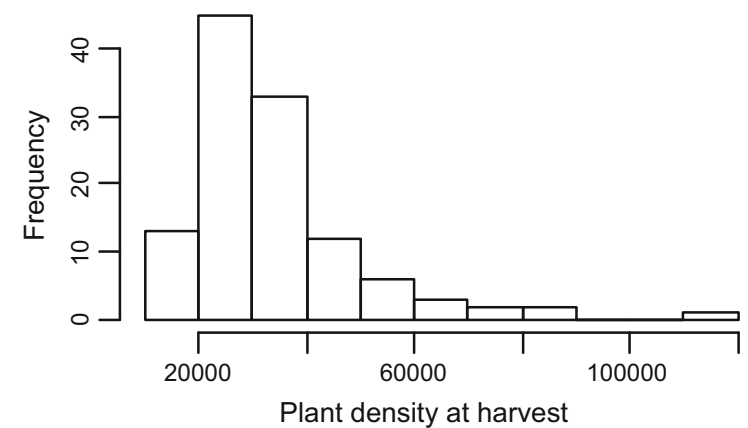

(d)

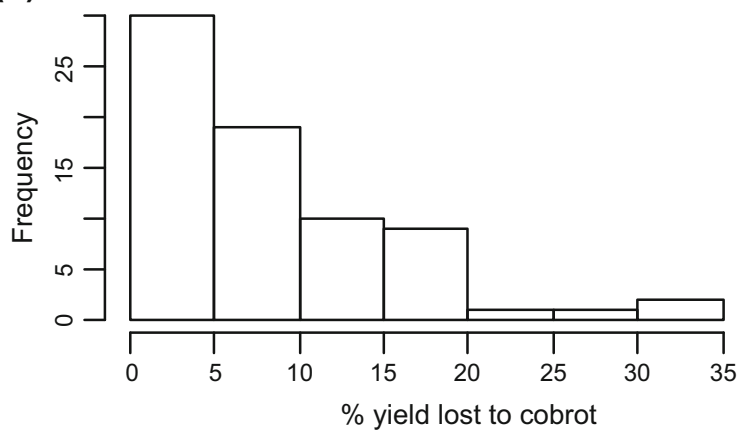

Fig. 3 Distributions of planting (a), plant density at harvest (b), manure application at different application frequencies (number of seasons out of five with manure application (c)) and relative pre-harvest yield loss (d) in farmer fields in Babati, northern Tanzania

We also observed that manure application decreased with distance from the homestead (data not shown).

Cob rot reduced yields within smallholder farms in Babati by an average of $7 \%$ although loss was up to $25 \%$ in some fields (Fig. 3d). Maximum pre-harvest yield loss was $800 \mathrm{~kg} \mathrm{ha}^{-1}$ and the mean was $244 \mathrm{~kg} \mathrm{ha}^{-1}$. Well managed fields e.g., the field used by extension officer for demonstration in one of the villages had all the cobs being very good and of much lower variability in cob sizes. Variety significantly 
Table 2 Prediction model parameters for maize grain yields obtained in Babati, Tanzania during the November 2012-July 2013 cropping season

\begin{tabular}{lrr}
\hline Parameter & Estimate & SE \\
\hline Variety: local or mixed (intercept) & 2633 & 09495 \\
Variety: DK & -008726 & 04221 \\
Variety: H614D & -07978 & 0494 \\
Variety: other improved seeds & 05214 & 03972 \\
Variety: pioneer & 05298 & 04952 \\
Variety: recycled & -1605 & 08401 \\
Variety: SC627 & 03282 & 03256 \\
Slope: flat & 07556 & 05521 \\
Slope: gentle & 001265 & 05575 \\
Slope: steep & -08936 & 07462 \\
Slope: very gentle & 02202 & 05717 \\
Plant density at harvest & 000003093 & 0000009505 \\
Distance from homestead & -02856 & 01247 \\
Lateness of planting & -0002828 & 0006688 \\
Years since land conversion to & -001787 & 0008968 \\
cultivation & & \\
\hline
\end{tabular}

affected pre-harvest cobrot-related maize grain yield losses $(P<0.01)$ with DK and Pioneer having the least $\left(150 \mathrm{~kg} \mathrm{ha}^{-1}\right)$ observed loss; the highest cobrotrelated yield loss of $280 \mathrm{~kg} \mathrm{ha}^{-1}$ was with SC627 (the most common improved variety) and with local varieties and mixed hybrids (data not shown).

In the yield modeling, factors that had a significant influence on the yield were slope $(P<0.01)$, plant density $(P<0.05)$, distance from homestead $(P<0.01)$, crop variety $(P<0.01)$, timing of planting $(P<0.01)$ and period that land was under cultivation (years since conversion; $P<0.05$ ). Omitting herbicide use, thinning, fertilizer application, frequency of manure application and weeding frequency did not affect the model significantly and the simplified model was not different from the full model as provided by the Anova test. As a result, these were removed in the final simplified model. The results indicate that the most common improved seed among farmers, SC627, improved yields over local varieties by $328 \mathrm{~kg} \mathrm{ha}^{-1}$ while other improved seeds including Pioneer had higher yields by $530 \mathrm{~kg} \mathrm{ha}^{-1}$ (Table 2). H614D and recycled improved seeds resulted in lower yields of about 800 and $1,600 \mathrm{~kg} \mathrm{ha}^{-1}$, respectively, compared to the local varieties. Fields on flat land obtained a further $756 \mathrm{~kg} \mathrm{ha}^{-1}$ over the mean yield while $894 \mathrm{~kg} \mathrm{ha}^{-1}$ less yield was obtained on the steep slopes. From the model, the difference between yield on flat and on steep slopes was huge, i.e., up to $1.6 \mathrm{t} \mathrm{ha}^{-1}$. Also, on the average, yields were lowered by $286 \mathrm{~kg} \mathrm{ha}^{-1}$ for every kilometer increase in distance of farm from homestead while every additional year of cropping decreased yield by $18 \mathrm{~kg} \mathrm{ha}^{-1}$. Similarly, average effect due to timing of planting was a yield reduction by $3 \mathrm{~kg} \mathrm{ha}^{-1}$ for each day delay while each additional plant contributing to plant density increased yield by $31 \mathrm{~g} \mathrm{plant}^{-1}$.

Classification trees are useful in understanding complex datasets. We used this to understand key determinants of yields gaps in farmer fields. Yield with plant density above 24,000 plants per hectare had $900 \mathrm{~kg} \mathrm{ha}^{-1}$ more grain yield than those whose density was lower (Fig. 4). Slope category influenced the yields where fields on the higher degree slopes (steep and gentle slopes) have suppressed yields (by $800 \mathrm{~kg} \mathrm{ha}^{-1}$ ) compared to fields on flat or on very gentle slopes, for fields with harvest density of $>24,000$. For all tree branches, there was consistently more yield for fields closer than fields further away from the homestead. For the more flat fields that were away from the backyard, yields were by $800 \mathrm{~kg} \mathrm{ha}^{-1}$ more in fields with frequent manure application (at least 2 in 5 years) than those with less frequent application.

As with yields across different farms and management regimes, there was high variation in yields within the same farmer field as illustrated by comparing yields from two replicates sampled in our survey (Fig. 5). These replicates were only $7 \mathrm{~m}$ apart within the same field. Averaged across all the fields, yields from replicate to replicate differed by $50 \%$. We observed a doubling of yield between the replicates in $15 \%$ of the fields. This variability is similar to one observed for two different fields (40 m apart) of the same farmer where 3 and $1.5 \mathrm{t} \mathrm{ha}^{-1}$ were observed, although this had been attributed to position; one in flat as opposed to on a steep slope (data not shown). The difference in yield between our two replicates was associated with the differences in plant density between the two replicates.

Nutrient inputs and outputs in farmer fields

Nutrient inputs in fields in Babati are mainly in the form of manure [and in exceptional cases foliar 


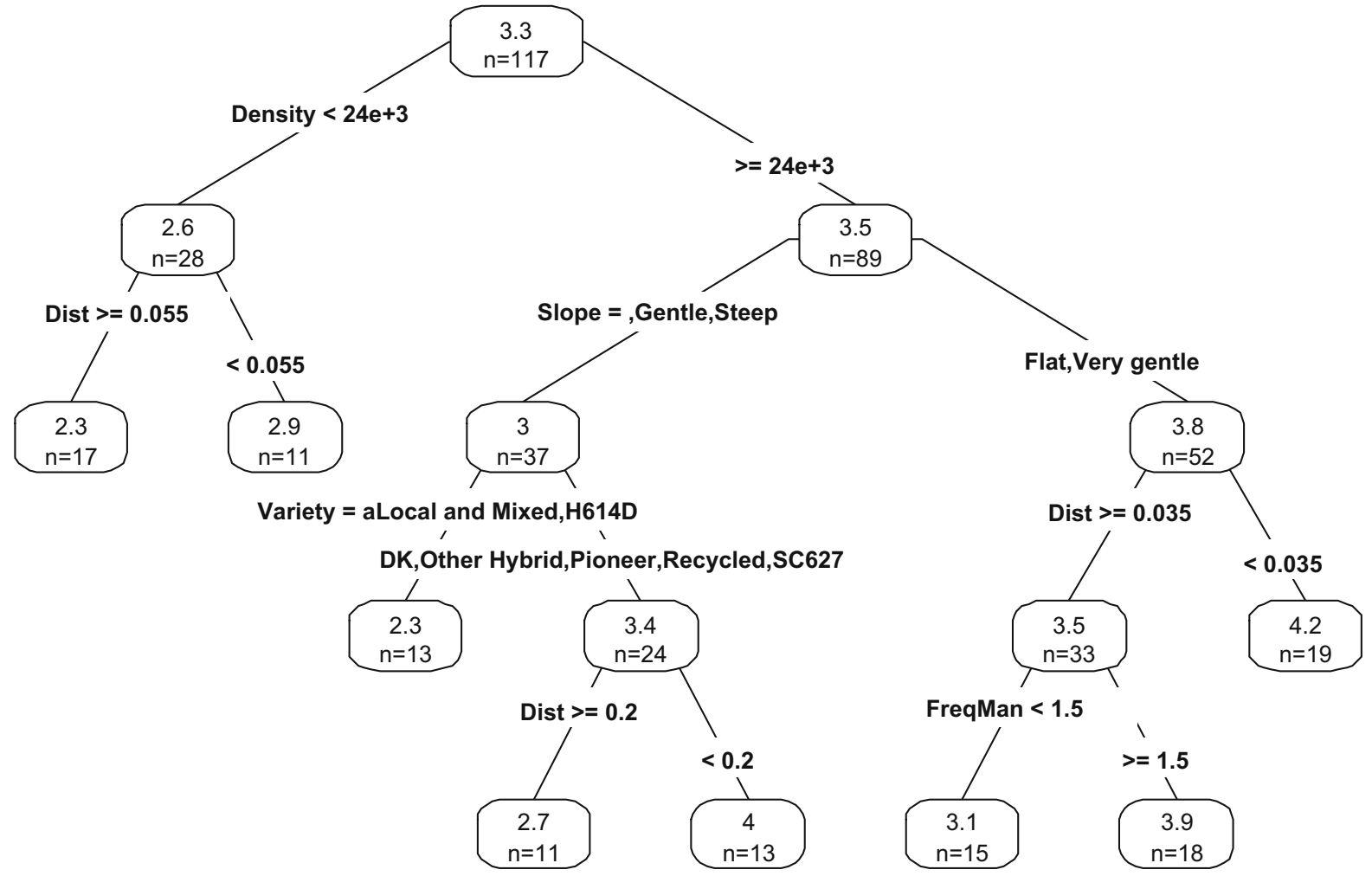

Fig. 4 Influence of key parameters on maize grain yield observed from various farmer fields in Babati, northern Tanzania. Boxes represent yield in $\mathrm{tha}^{-1} n=$ number of fields, dist $=$ distance from homestead in $\mathrm{km}$, FreqMan $=$ frequency of manure application in seasons, Density = plant density (a)

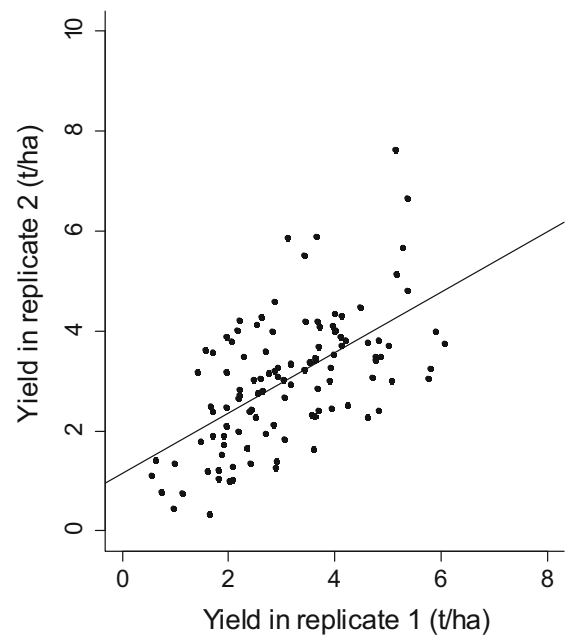

Fig. 5 Yield variations between two sampling replicates in different farmer fields surveyed (a) and relationship between replicate differences in observed maize grain yield and plant (b)

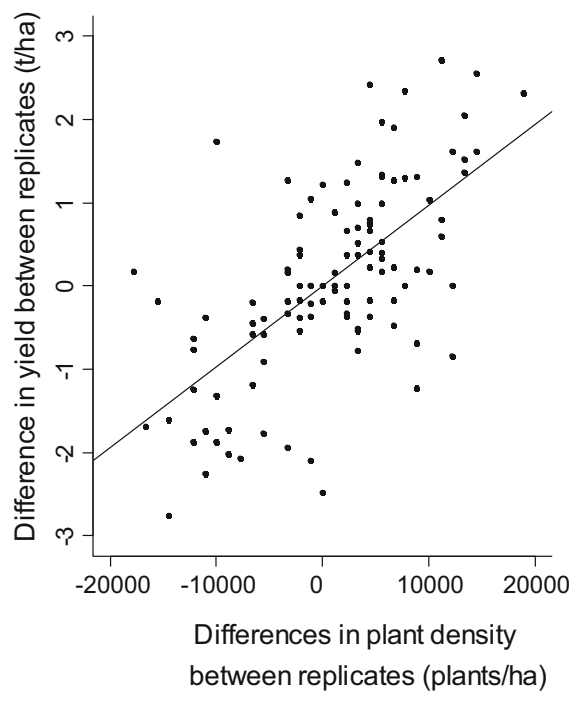

density at harvest (b) in Babati, northern Tanzania. Solid line through the data points is a regression line 

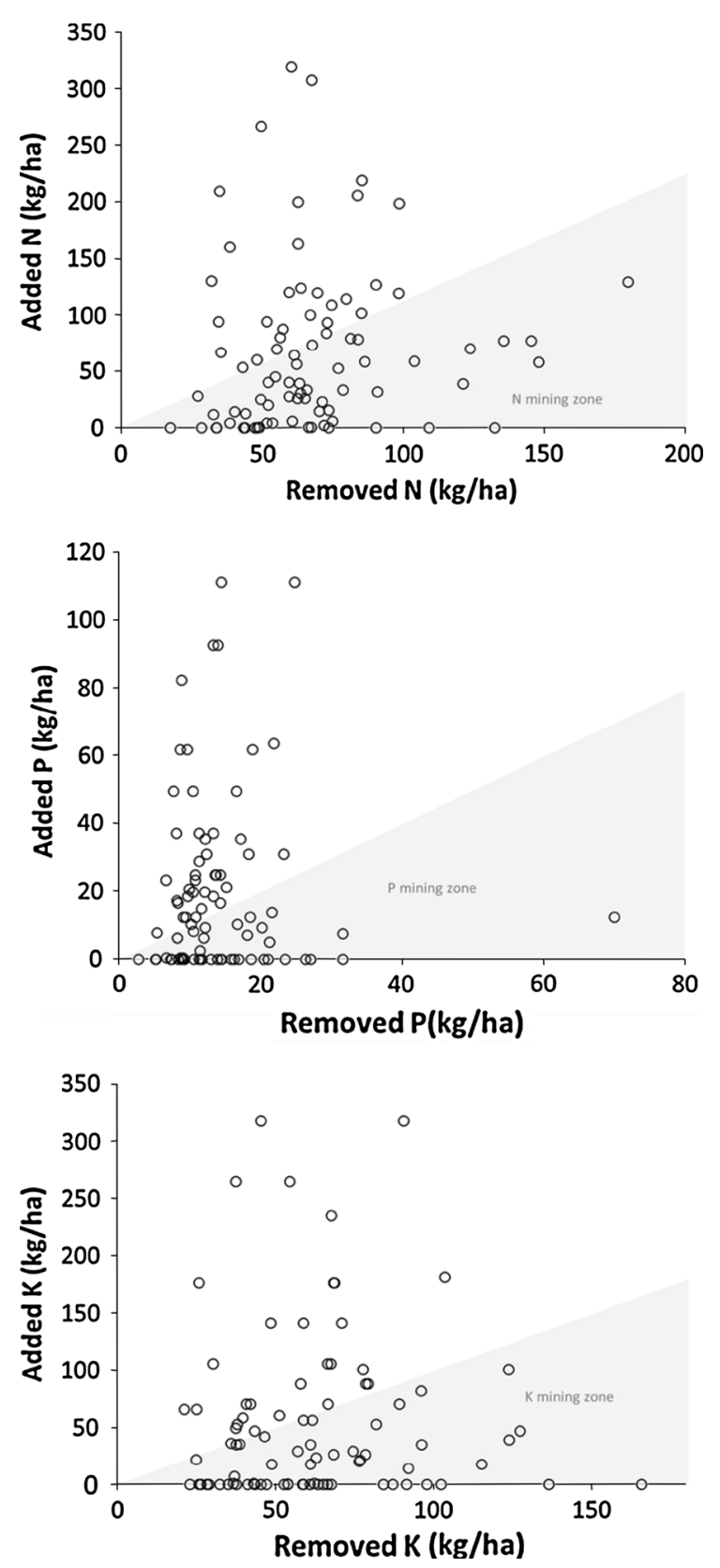

Fig. 6 Relationship between applied and removed nutrients in on-farm fields in Babati, northern Tanzania Additions and removals cover the period August 2012 to August 2013

fertilizers-NPK application (Booster)] and legume BNF (especially pigeonpea). Nutrient outputs include removal of crop produce, $100 \%$ stover for animal feed and $100 \%$ pigeonpea stalks for fuelwood. Most fields are thus exposed to nutrient mining, having higher nutrient removals than additions (Fig. 6). The majority of the farmer fields had negative nutrient balances (at least $74 \%$ for N, $52 \%$ for P and $66 \%$ for $\mathrm{K}$ ) indicating mining of the soil. Most of the fields with higher productivity of pigeonpea were associated with low $\mathrm{N}$ mining compared to fields without pigeonpea. Despite that manure is almost the only source of nutrient $\mathrm{P}$ and $\mathrm{K}$ inputs, positive balances were observed for farmers who applied higher amounts of manure.

\section{Discussions}

Sustainable intensification is considered to be a key goal in most production systems. However, its realization requires that several production variables are optimized. While many regions of the world have progressed to precision farming (Oliver and Robertson 2013), basic agronomic practices in SSA are still far from being optimal. As observed in our study, yield reducing factors include low plant populations, increasing slope, distance from homestead and number of years since land conversion to cultivation, reduced frequency of manure application and delayed planting. Others have observed inadequate weed control as an important factor as well (Fanadzo et al. 2011; Tittonell et al. 2008). The low plant densities by majority of farmers in our study and the less than half of targeted 41,100 plant $^{-1} a^{-1}$ in the study by Fanadzo et al. (2011) indicate that indeed basic agronomy is key to addressing part of the yield gap in SSA. Manure has been shown to increase yields (Zingore et al. 2008) and our study further shows that farmers who apply large quantities of manure apply it more frequently but not efficiently than those with less amounts of manure. Further, planting late, a practice discouraged by other researchers (Ajanga and Hillocks 2000), clearly decreased yields in farmer fields, and farmers associated it with poor germination and increasing cobrot, although our models indicated variety is what influenced cobrot. Recycling hybrid seed resulted in high yield reductions, but modest decline, similar or higher yields especially when compared to open pollinated varieties have been observed elsewhere (Zambezi et al. 1997). Reduced yield with H614D was not expected although seasonal climate may have affected this long duration variety (duration to maturity: 180-190 days). High use of improved maize seeds, also reported as $55 \%$ of farmers by Amare et al. 
(2012) and as "high" by Nkonya et al. (1998), contrasts the extremely low use of fertilizer, also observed as less than $5 \%$ by Adu-Gyamfi et al. (2007) for the same study site. The high yields achieved in some of the fields indicate that crop productivity in Babati can be well improved with good management.

The decreasing yields with each additional year that the land is under cultivation, distance from the homestead as well as slope steepness are indications of continuous deterioration of soil/land health in Babati. This is consistent with chronosequence studies where a steep decline in soil fertility with period of cultivation is observed (Isaac et al. 2005; Lal 2006). Also, soil erosion indices increase with slope steepness (Koulouri and Giourga 2007) and for our study site, complete removal of crop residue certainly aggravates soil erosion as also reported elsewhere (Giller et al. 2011). The reduced yield for fields on steep to gentle sloping fields (no contours or erosion control bands in place in our study fields) is an indication of the greater degradation occurring on the sloping fields. Implementing conservation measures on the steep slopes, which are otherwise excellent niches for some fodder/forage crops could stabilize soil and mitigate further degradation (Leihner et al. 1996). Fields further away from the homestead are disadvantaged in terms of inputs of organic resources such as manure, and are characterized by low organic matter (Zingore et al. 2008; Giller et al. 2011), since in some cases, the manure is inadequate for the whole field or all parcels. In Kenya, Tittonell et al. (2005) observed greater $\mathrm{P}$ and $\mathrm{K}$ in home fields than in remote fields. Thus measures to conserve the production base are needed if productivity decline is to be arrested (Isaac et al. 2005; Lal 2006) and Lal (2006), for example, shows that up to $300 \mathrm{~kg} \mathrm{ha}^{-1}$ of maize grain increase can be obtained for every $1 \mathrm{Mg} \mathrm{ha}^{-1}$ increase in soil organic carbon pool in the root zone, which corresponds to yield loss for every kilometer away from the homestead in our study.

The average yield loss due to cobrot is similar to the overall effect of manure of $220 \mathrm{~kg} \mathrm{ha}^{-1}$ (data not shown) which calls for the need to think of holistic approaches to address all yield limiting factors in farmer fields. Ajanga and Hillocks (2000) found more than $20 \%$ incidences of cobrot in western Kenya and suggested early planting and management of stalkborer as the appropriate strategies. The absence of rotation in our study site may contribute to the extreme effects of Gibberella cobrot observed (besides the cool, moist weather conditions at flowering).

High maize yield variability is reported in SSA compared to other tropical environments, e.g., seasonal variations (Smale et al. 2013). The observed replicate to replicate variations in our study are interesting since only $7 \mathrm{~m}$ separated the two sampling plots in each field. Besides plant density as reported in the current study, variations in soil fertility (a consequence of historical management; Tittonell et al. 2008) and preferential management including input use and timing of weeding are key factors responsible for yield variability within individual farms (Giller et al. 2011; Zingore et al. 2008; Tittonell et al. 2008). Manure is often applied in random heaps, scattered by hand around each heap followed by ploughing. Although variations in soils have been investigated even at fine scales (Scott-Wendt et al. 1988; Davis et al. 1995; Brouwer et al. 1993), there are hardly any studies relating crop production with soils at very fine scales within SSA. Besides management, topographic variations within a field contribute to variations in yields and in Australia, Scott-Wendt et al. (1988) showed that poor crop stands tend to be associated with micro-low as opposed to micro-high regions. Sub-Sahara Africa, unlike the industrialized countries where fertilizer inputs can be matched with yield variations at the sub-field scale (Oliver and Robertson 2013), will have to grapple with the variability through visual observations until applicable site-specific diagnostic tools are developed. In many cases, visual symptoms show up when it is too late to apply effective remedial measures.

Negative nutrient balances are indicative of nutrient mining and could impact on future agricultural productivity (Bindraban et al. 2000). Large negative input-output balances in farmer fields in Babati are consistent with finding of Adu-Gyamfi et al. (2007) for the same site, and generally for farming systems in SSA (Stoorvogel et al. 1993). These negative nutrient budgets in the intercropping systems in Babati could be reduced by up to $80 \%$ for $\mathrm{N}$ and $30 \%$ for $\mathrm{P}$ by exporting only grains rather than all above ground biomass (Adu-Gyamfi et al. 2007). On the other hand, high nutrient additions accompanied by low removals in some fields result in high positive balances because nutrients are not utilized by the plants and yet yield gaps still exists. There is thus an opportunity to optimize nutrient use efficiencies through adjustments 
in manure applications. Kihara et al. (2011) for example showed that combination of manure with maize stover result in better yield than where manure is used alone and this was attributed to the faster release of nutrients from manure than needed by plants. Overall, increasing frequency of manure application is important for increased maize grain yields in Babati, despite that amount of manure application decreases towards outfields. The nutrient budgets were improved for farmers who applied manure (as also in AduGyamfi et al. 2007) and where pigeonpea yield was high. Unlike $\mathrm{P}$ and $\mathrm{K}, \mathrm{N}$ budgets are not a major concern since $\mathrm{N}$-fixation from pigeonpea in Babati has been estimated as $54 \mathrm{~kg} \mathrm{ha}^{-1}$ (Adu-Gyamfi et al. 2007). The manure application is best supplemented with chemical fertilizers that are presently almost not in use (see also Adu-Gyamfi et al. 2007).

Manure in our study site is usually used as indoor bedding for the animals at night. Fresh manure is usually removed from the sleeping area, spread thin to dry in the sun (without mixing with anything) and is then returned to the sleeping area in the evening. Advantages include warmth for animal at night, to avoid sinking holes in the house floor and to keep the animals clean. There is evidence of yield improvement due to manure despite its current mode of management.

In studies involving yield assessment in farmer fields, it is important to provide feedback to the farmers. The results from this study were presented in feedback meetings to the national staff and farmers who confirmed that the models described their situation well. Our study, however, did not ask farmers why they managed fields in a specific way and did not also consider how household typology influence yields in farmer fields and future studies can consider these aspects. The socio-economic situation of the farmers may influence why farmers for example farm on steep slopes or do not apply organic resources to outfields leading to low yields. Also, our study does not relate amount and frequency of manure use with livestock ownership nor attempted to find out if farmers purchased manure from livestock farmers. Future studies should investigate these aspects.

\section{Conclusions}

We have demonstrated the use of agronomic survey to assess yield gap and gain insight in management practices at small-scale farmer level and their influences on yields. We also present different analysis techniques for mining information from the data. Optimizing plant density in farmer fields, higher frequency of manure application and choice of crop varieties are important to reducing yield gaps. Cropping systems used in Babati should be supplemented with mineral fertilizers to reduce nutrient mining and address identified deficiencies in Zn, P and S. Further work is needed to assess manure quality and improve manure handling.

Acknowledgments This study was sponsored by IITA through the USAID Feed the Future's Africa RISING Program. We recognize extension officers at Long village ( $\mathrm{Mr}$ Zahoro Madongo) and Seloto Village (Madam Elda) for their role in data collection and sensitizing farmers in Babati study site, IITA special program officer $\mathrm{Mr}$ Festo Ngulu for orientation and participating in the groundwork activities culminating to this study. We also acknowledge Mrs Wanjiku Kiragu for providing important critique at the initial stages of this manuscript. Ann Njeri is acknowledged for providing valuable editorial input and proof-reading the final version of the manuscript.

Open Access This article is distributed under the terms of the Creative Commons Attribution License which permits any use, distribution, and reproduction in any medium, provided the original author(s) and the source are credited.

\section{References}

Adu-Gyamfi JJ, Myaka A, Sakala WD, Odgaard R, Vesterager JM, Høgh-Jensen H (2007) Biological nitrogen fixation and nitrogen and phosphorus budgets in farmer-managed intercrops of maize-pigeonpea in semi-arid southern and eastern Africa. Plant Soil 295:127-136

Ahiabor BD, Hirata H (2003) Associative influence of soluble phosphate, rock phosphate and Arbuscular mycorrhizal fungus on plant growth and phosphorus uptake of three tropical legumes. West Afri J Appl Ecol 4:75-90

Ajanga S, Hillock RJ (2000) Maize cob rot in Kenya and its association with stalk borer damage. Crop Prot 19:297-300

Amare M, Asfaw S, Shiferaw B (2012) Welfare impacts of maize-pigeonpea intensification in Tanzania. Agric Econ 43:27-43

Arias A, Hallam D, Krivonos E, Morrison J (2013) Smallholder integration in changing food markets. FAO, Rome, Italy

Bindraban PS, Stoorvogel JJ, Jansen DM, Vlaming J, Groot JJR (2000) Land quality indicators for sustainable land management: proposed method for yield gap and soil nutrient balance. Agric Ecosyst Environ 81:103-112

Brouwer J, Fussell LK, Herrmann L (1993) Soil and crop growth micro-variability in the West African semi-arid tropics: a 
possible risk-reducing factor for subsistence farmers. Agric Ecosyst Environ 45:229-238

Davis JG, Hossner LR, Wilding LP, Manu A (1995) Variability of soil chemical properties in two sandy, dunal soils of Niger. Soil Sci 159:321-330

Fanadzo M, Chiduza C, Mnkeni PNS, van der Stoep I, Stevens J (2011) Crop production management practices as a cause for low water productivity at Zanyokwe Irrigation Scheme. Water SA 36:27-36

Giller KE, Tittonell P, Rufino MC, van Wijk MT, Zingore S, Mapfumo P, Adjei-Nsiah S, Herrero M, Chikowo R, Corbeels M, Rowe EC, Baijukya F, Mwijage A, Smith J, Yeboah E, van der Burg WJ, Sanogo OM, Misiko M, de Ridder N, Karanja S, Kaizzi C, K'ungu J, Mwale M, Nwaga D, Pacini C, Vanlauwe B (2011) Communicating complexity: integrated assessment of trade-offs concerning soil fertility management within African farming systems to support innovation and development. Agric Syst 104:191-203

Høgh-Jensen H, Myaka FA, Sakala WD, Kamalongo D, Ngwira A, Vesterager JM, Odgaard R, Adu-Gyamfi JJ (2007) Yields and qualities of pigeonpea varieties grown under smallholder farmers' conditions in Eastern and Southern Africa. Afr J Agric Res 2:269-278

Isaac ME, Gordon AM, Thevathasan N, Oppong SK, QuashieSam J (2005) Temporal changes in soil carbon and nitrogen in West African multistrata agroforestry systems: a chronosequence of pools and fluxes. Agrofor Syst 65:23-31

Kihara J, Bationo A, Mugendi DN, Martius C, Vlek PLG (2011) Conservation tillage, local organic resources and nitrogen fertilizer combinations affect maize productivity, soil structure and nutrient balances in semi-arid Kenya. Nutr Cycl Agroecosyst 90:213-225

Kimani SK, Lekasi JK (2004) Managing manures throughout their production cycle enhances their usefulness as fertilisers: a review. In: Bationo A (ed) Managing nutrient cycles to sustain soil fertility in sub-Saharan Africa CIATTSBF, Nairobi, Kenya, pp 187-197

Kimaro AA, Timmer VR, Chamshama SAO, Kimaro DA (2009) Competition between maize and pigeonpea in semi-arid Tanzania: effect on yields and nutrition of crops. Agric Ecosyst Environ 134:115-125

Koulouri M, Giourga C (2007) Land abandonment and slope gradient as key factors of soil erosion in Mediterranean terraced lands. Catena 69:274-281

Lal R (2006) Enhancing crop yields in the developing countries through restoration of the soil organic carbon pool in agricultural lands. Land Degrad Develop 17:197209

Leihner DE, Ruppenthal M, Hilger TH, Castillo F (1996) Soil conservation effectiveness and crop productivity of forage legume intercropping, contour grass barriers and contour ridging in Cassava on Andean Hillsides. Expr Agric 32:327-338

Muller ND, Gerber JS, Johnston M, Ray DK, Ramankutty N, Foley JA (2012) Closing yield gaps through nutrient and water management. Nature 490:254-257
Myaka MF, Sakala WD, Adu-Gyamfi JJ, Kamalongo D, Ngwira A, Odgaard R, Nielsen NE, Høgh-Jensen H (2006) Yields and accumulations of $\mathrm{N}$ and $\mathrm{P}$ in farmer-managed intercrops of maize-pigeonpea in semi-arid Africa. Plant Soil 285:207-220

Nkonya E, Xavery P, Akonaay H, Mwangi W, Anandajayasekeram P, Verkuijl H, Martella D, Moshi A (1998) Adoption of maize production technologies in Northern Tanzania. International Maize and Wheat Improvement Center (CIMMYT), The United Republic of Tanzania, and the Southern African Center for Cooperation in Agricultural Research (SACCAR), Mexico DF

Oliver YM, Robertson MJ (2013) Quantifying the spatial pattern of the yield gap within a farm in a low rainfall Mediterranean climate. Field Crops Res 150:29-41

Paul S, Onduru D, Wouters B, Gachimbi L, Zake J, Ebanyat P, Ergano K, Abduke M, van Keulen H (2009) Cattle manure management in East Africa: review of manure quality and nutrient losses and scenarios for cattle and manure management. Wageningen University Report 258

Scott-Wendt J, Chase RG, Hossner LR (1988) Soil chemical variability in sandy ustalfs in Semiarid Niger, West Africa. Soil Sci 145:414-419

Silim SN, Gwataa ET, Coeb R, Omanga PA (2007) Response of pigeonpea genotypes of different maturity duration to temperature and photoperiod in Kenya. Afr Crop Sci J 15:73-81

Smale M, Byerlee D, Jayne T (2013) Maize revolutions in subSaharan Africa. In: Otsuka K, Larson DF (eds) An Africa green revolution: finding ways to boost productivity on small farms. Springer Science + Business Media, Dordrecht, pp 165-195

Stoorvogel JJ, Smaling EMA, Janssen BH (1993) Calculating soil nutrient balances in Africa at different scales. Fertil Res 35:227-235

Tittonell P, Vanlauwe B, Leffelaar PA, Shepherd KD, Giller KE (2005) Exploring diversity in soil fertility management of smallholder farms in western Kenya: II. Within-farm variability in resource allocation, nutrient flows and soil fertility status. Agric Ecosyst Environ 110:166-184

Tittonell P, Shepherd KD, Vanlauwe B, Giller KE (2008) Unravelling the effects of soil and crop management on maize productivity in smallholder agricultural systems of western Kenya-an application of classification and regression tree analysis. Agric Ecosyst Environ 123:137150

Zambezi BT, Nyondo FK, Nkhono G, Mbingwani GF, Chakhuta TF (1997) Evaluation of recycled maize hybrids at three levels of nitrogen in Malawi. In: Ransom JK, Palmer AFE, Zambezi BT, Mduruma ZO, Waddington SR, Pixley KV, Jewell DC (eds) Maize productivity gains through research and technology dissemination. Proceedings of the Fifth Eastern and Southern Africa Regional Maize Conference. 3-7 June, Arusha, Tanzania. CIMMYT, Nairobi

Zingore S, Delve RJ, Nyamangara J, Giller KE (2008) Multiple benefits of manure: the key to maintenance of soil fertility and restoration of depleted sandy soils on African smallholder farms. Nutr Cycl Agroecosyst 80:267-282 